\title{
Oligotrophication after a nutrient reduction in a shallow sand-pit lake (Créteil Lake, Paris suburbs, France) : a case of rapid restoration
}

\author{
J. Garnier ${ }^{*}$ \\ A. Chestérikoff 2 \\ P. Testard 1 \\ B. Garban 2
}

Keywords : shallow lake, sand-pit, nutrient reduction, oligotrophication.

A limnological study was performed out, over 8 years from 1979 to 1986, in a shallow recently created sand-pit lake, Lake Créteil (Paris suburb, France). The lake is mainly supplied by phreatic waters. Typical of shallow waters, thermal stratification which occurred from May to October was intermittently broken by wind, leading to high seasonal fluctuations and allowing a reoxygenation of the total water column. The interannual development of the lake was characterized by a regular increase in transparency (from $1 \mathrm{~m}$ in 1979 to $2.7 \mathrm{~m}$ in 1985) which was partly due to not only stabilization of the bottom sediment and the banks, but also to a reduction of the biological component. A decrease in chiorophyll $a$ concentrations resulted from nutrient diversion of domestic inputs collected through the rainwater pipe coming into the lake. The rapid restoration of water quality shows that this small artificial lake is very sensitive to human interventions.

Oligotrophisation d'une sablière en eau (Lac de Créteil, région parisienne, France) après une réduction des apports en éléments nutritifs : un cas de rapide restauration

Mots clés : lac peu profond, sablière en eau, réduction en éléments nutritifs, oligotrophisation

La tendance évolutive d'un lac artificiel de création récente a été étudiée pendant 8 années consécutives, de 1979 à 1986 (Lac de Créteil, banlieu parisienne, France). Ce lac de sablière, peu profond, est essentiellement alimenté par les eaux d'une nappe superficielle. En raison des stratifications et destratifications intermittentes liées au vent, invariablement observées d'avril à octobre, l'évolution saisonnière du lac se caractérise par des fluctuations importantes ; les phases de déstratification permettent une réoxygénation de la colonne d'eau. L'évolution interannuelle du lac s'est caractérisée par une augmentation régulière de la transparence des eaux ( $-1 \mathrm{~m}$ en 1979 à $-2.7 \mathrm{~m}$ en 1985) due à la stabilisation des berges et des sédiments, mais aussi à la diminution de la composante biologique. La diminution du stock phytoplanctonique (concentration en chlorophylle a) est clairement liée à la réduction des apports domestiques rejetés dans le lac jusqu'en mai 1981 par un collecteur d'eau de pluie. L'amélioration particulièrement rapide de la qualité de l'eau montre que ce milieu est très sensible aux aménagements.

\section{Introduction}

Limnological studies have mainly focused on natural lakes; some of them are particularly well documented in literature (Constance, Geneva, Vic-

1. Laboratoire de Géologie Appliquée, U.A. 1367 C.N.R.S., 4. Place Jussieu, Tour 26, 5* étage, 75005 Paris, France.

- Present adress : Groupe de Microbiologie des Milieux Aquatiques, Unjersité Libre de Bruxelles, Campus de la Plaine, CP 221,1050 Bruxelles, Belgique.

2. Institut d'Hydrobiologie et de Climatologie, 4, Place Jussieu, Tour 26, 5e etage, 75005 Paris, France. toria, Balaton or Windermere lakes...) whereas the knowledge of others have even been recently integrated into books (Mendota Lake : Billings et al. (1985), Mirror Lake : Likens (1985), Stechlin Lake . Caspers (1985)). More recently, a book was proposed analysing reservoir functioning (Thornton et al. 1990).

Although sand-pit lakes have become more and more numerous in the last few years, due to the increasing need in building materials, less attention has been paid to these kind of ecosystems. Some ecological characteristics of several sand-pit lakes have however been given in Garnier et al. (1987). 
The sand-pit lake of Créteil (Paris suburb, France) has been intensively studied for 8 years. The study started in 1979 soon after the quarrying of sand has finished in 1976. The study period can therefore be considered as a field experiment around the following question : how long would be necessary for this young system to achieve a relative stability ? Such a recently created system was a priori appropriate to interpret the possible process of naturalization of an artificial aquatic system. However, situated in a town, the role of Lake Créteil as a recreational and ornamental area has required several management measures which interfered with natural processes. The paper analyses the seasonal and interannual changes of that young artificial aquatic system.

\section{Site study}

Créteil lake is situated in an urbanized area near the confluence of the Marne and Seine rivers $15 \mathrm{~km}$ SE of Paris, France (Fig. 1). Parisian Basin has a temperate climate and has been rather stable for the period studied, although some year-to-year variability has been observed. A summary of annual mean and extreme values is given for global incident radiation, temperature, rainfall and wind (Table 1).

The Créteil sand-pit lake originated from the excavation, between 1947 to 1976 , of the alluvial sediments. The alluvial plain is delimited by the Seine (West) and Marne rivers (North) and by Tertiary outcrops (East, South). Créteil Lake is not connected with the rivers. The lake is mainly supplied by anoxic phreatic waters of the alluvial aquifer, water circulating mainly through diverse filling materials which have replaced the natural alluvium dug out in the past. Besides direct rainfall, the lake also receives rainwater runoff from the $0.5 \mathrm{~km}^{2}$ of the Mont Mesly urbanized zone. The water residence time in the lake was estimated at 6-12 months (Chestérikoff 1981). The high total salinity $\left(1.4 \mathrm{~g} \mathrm{1}^{-1}\right)$ of Lake Créteil water originates from the composition of the supplying underground water (Table 2 ). The dominance of calcium and sulfate is mainly caused by the gypsum strata of Mont Mesly outcrops whereas the high concentration of sodium and chloride is due to the filling materials. Total salinity in the water coming from the rainwater pipe is lower $(0.87 \mathrm{~g}$ 1-1). Data collected from 1978 to 1980 and again in 1986, show that the ionic composition of the lake water has been rather stable for the period studied, although it slightly decreased in 1986 (Table 2).

The surface area of the lake is $0.42 \mathrm{~km}^{2}$; maximal length and width are 1.5 and $0.4 \mathrm{~km}$ respectively following a NS axis. The banks are steep so that macrophytes occupy only $15 \%$ of their length. The lake is surrounded by buildings at East and NorthEast, an artificial hill at West ; it is exposed to wind from the South and South-East. The depth of the lake is homogenous within most of its surface area but maximal depth has varied between 4 and $5 \mathrm{~m}$.

During the study period, different management measures were successively taken, which all perturbed the trend of the lake functioning.

1981: The rainwater run off collected on the urbanized watershed and brought to the lake by a pipe was accompanied by polluted domestic water at the beginning of the study. In May 1981, the polluted inputs were lowered.

1983 : The water level of the lake regularly increased $(1.27 \mathrm{~cm} / \mathrm{month})$ from 1979 to 1982 due to the consolidation of ground materials following the construction of an artificial hill (Chestérikoff \& Chevreuil 1987), although this increase might also be caused by the increase in rainfall observed during that period (Table 1). At the beginning of 1983, a drainage pipe of $500 \mathrm{l} / \mathrm{sec}$ in capacity was set to regulate the level of the lake, decreasing the residence time.

1985 : From December 1985 to August 1986, intensive pumpings of phreatic waters led to a regular decrease of the water level $(3 \mathrm{~cm} /$ week, i.e. $1 \mathrm{~m}$ in total) ; initial values were then found when pumping ceased.

\section{Material and methods}

The study was carried out in the central area of the lake from 1979 to 1986 at intervals ranging from a week in summer to a month in winter.

Measurements of temperature and oxygen were performed in depth profiles with intervalls of $50 \mathrm{~cm}$, with a YSI (model 57) probe. Wind speeds were recorded at a meteorological station in the nearby 

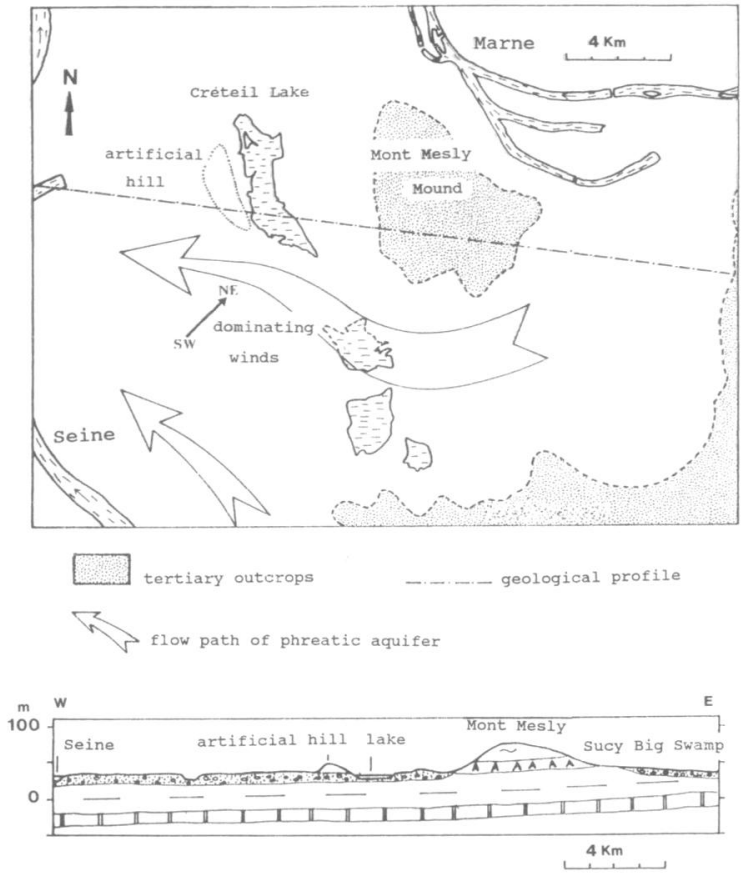

* $\%$ recent and old

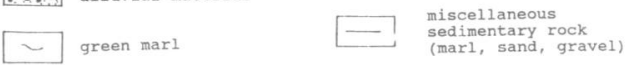

* A gypsum

* $\square$ block limestone

* aquifer

Fig. 1. Situation of Créteil Lake. Cross-section of the plain of Créteil (according to Chestérikoff \& Chevreuil 1987).

Fig. 1. Situation du lac de Créteil. Coupe géologique de la plaine de Créteil (D'après Chestérikoff \& Chevreuil 1987). 
Table 1. Interannual variations, from 1979 to 1986, of annual means (x) and extreme values (min, max) for global incident radiation

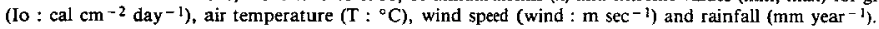

Tableau 1. Variations interannuelles, de 1979 à 1986. des moyennes anjuelles (x) et des valeurs extrêmes (min, max) de la radiation globale incidente (Io : $\mathrm{cal} \mathrm{cm}^{-2} \mathrm{j}^{-1}$ ), de la température de l'air $\left(\mathrm{T}:{ }^{\circ} \mathrm{C}\right)$, de la vitesse du vent ( $\mathrm{m} \mathrm{sec}^{-1}$ ) et de la hauteur annuelle des précipitations (mm).

\begin{tabular}{|c|c|c|c|c|c|c|c|c|c|}
\hline & & 1979 & 1980 & 1981 & 1982 & 1983 & 1984 & 1985 & 1986 \\
\hline \multirow[t]{3}{*}{ Io } & $x$ & 244 & 239 & 241 & 262 & 263 & 255 & 256 & 249 \\
\hline & $\min$ & 9.1 & 8.8 & 17.2 & 9.8 & 14.3 & 9.3 & 16.7 & 6 \\
\hline & $\max$ & 649 & 667 & 715 & 705 & 656 & 706 & 698 & 812 \\
\hline \multirow[t]{3}{*}{$\mathbf{T}$} & $x$ & 10.6 & 10.6 & 11.7 & 11.9 & 11.6 & 10.9 & 10.8 & 10.8 \\
\hline & $\min$ & -10.8 & -7.3 & -5.3 & -8.1 & -5.2 & -5.3 & -16.4 & $=10.6$ \\
\hline & $\max$ & 33.9 & 33.4 & 33.8 & 34.1 & 36.1 & 36.3 & 33.2 & 33.7 \\
\hline \multirow[t]{3}{*}{ wind } & $x$ & 1.92 & 1.96 & 2.38 & 2.63 & 2.77 & 2.46 & 2.45 & 2.6 \\
\hline & $\min$ & 0 & 0 & 0 & 0.3 & 0.1 & 0.1 & 0 & 0.1 \\
\hline & $\max$ & 6.5 & 7.3 & 10.4 & 8.1 & 8.8 & 8.1 & 7.8 & 7.9 \\
\hline \multicolumn{2}{|c|}{ Rainfall } & 571.3 & 641.8 & 743.6 & 784.0 & 590.7 & 733.2 & 482.5 & 640.6 \\
\hline
\end{tabular}

Table 2. Comparative conductivity $\left(\mu \mathrm{S} \mathrm{cm}^{-1}\right)$ and major elements $\left(\mathrm{mg} \mathrm{l}^{-1}\right)$ of the waters. Phreactic waters : range of values for the 7 to 9 different piezometers and exceptional high or low values in parentheses (Chestérikoff et al., 1981). Pipe waters : extremes values (ext) and mean $(x)$ (Chestérikoff et al. 1981). Lake waters : mean values in 1978-1979 (Chestérikoff et al. 1981), in 1980 (Chestérikoff 1981) and in 1986.

Tableau 2. Valeurs comparatives de la conductivité $\left(\mu_{\mathrm{S} \mathrm{cm}}^{-2}\right)$ et des éléments majeurs dans l'eau et dans la nappe. Eau de la nappe : amplitude des valeurs pour 7 à 9 piézomètres et valeurs exceptionnellement basses ou élevées entre parenthèses (Chestérikoff et al., 1981). Eaux du collecteur : valeurs extrêmes (ext) et moyenne (x) (Chestérikoff et al., 1981). Eaux du lac ; valeurs moyennes en 1978-1979 (Chestérikoff et al. 1981), en 1980 (Chestérikoff 1981) et en 1986.

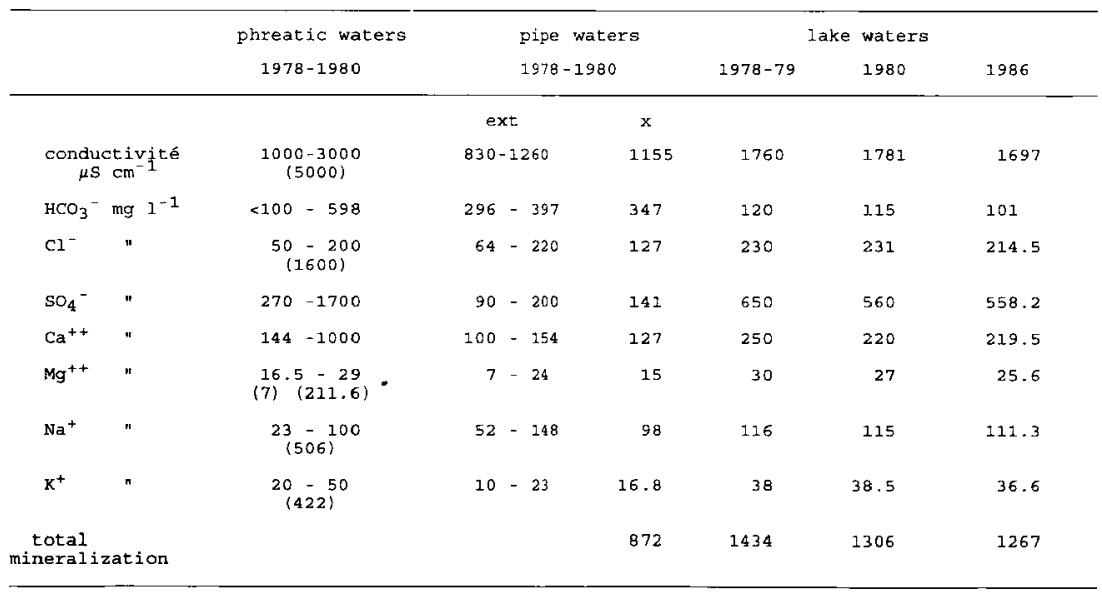


environment. Global radiation was also continuously recorded with a pyranograph (Eppley) equiped with an integrator (Mecilec) at the meteorological station. Light attenuation profiles were established every $20 \mathrm{~cm}$, with a quantameter coupled with an integrator (LI $193 \mathrm{~S}$, LI 188). Vertical attenuation coefficient $(\mathrm{K})$ was calculated from a linear regression given by the equation: $\mathrm{LnQ}_{z}=\mathrm{Kz}+$ $\mathrm{LnQ}_{\mathrm{o}}$ where $\mathrm{Q}_{\mathrm{o}}$ and $\mathrm{Q}_{z}$ are the irradiance under the surface and at the depth $z$. Transparency was estimated with a Secchi disk (white, $30 \mathrm{~cm}$ diameter).

Nutrient analyses were carried out on the water taken at $1.5 \mathrm{~m}$ from 1979 to 1981 and on a mixed water sample of six depths $(0,0.5,1,1.5,2.5$ and $4 \mathrm{~m}$ ) from 1982 to 1986. Water samples for $\mathrm{P}_{-} \mathrm{PO}_{4}$, $\mathrm{N}-\mathrm{NO}_{3}$ and $\mathrm{N}-\mathrm{NH}_{4}$ were filtered through $\mathrm{GF} / \mathrm{F}$ membrane filters and frozen until analyses. $\mathrm{P}-\mathrm{PO}_{4}$ was measured by spectrophotometer at $630 \mathrm{~nm}$ after a reaction with ammonium molybdate and a reduction to molybdenium blue by ascorbic acid. Total Phosphorus (P-tot) was determined as above on unfiltered lake water after sodium persulfate digestion and mineralization at $110^{\circ} \mathrm{C}$ in acidic phase. $\mathrm{N}-\mathrm{NO}_{3}$ was spectrophotometrically measured at $415 \mathrm{~nm}$ after the formation of Na-paranitrosalicylate whereas $\mathrm{N}-\mathrm{NH}_{4}$ was determined at $635 \mathrm{~nm}$ by the indophenol method. As relatively small values of $\mathrm{N}-\mathrm{NO}_{2}$ were measured at the beginning of the study, total inorganic nitrogen ( $\mathrm{N}$-tot) was considered to be the sum of $\mathrm{N}-\mathrm{NO}_{3}$ and $\mathrm{N}-\mathrm{NH}_{4}$, although $\mathrm{N}-\mathrm{NO}_{2}$ might have developped transiently as a result of degradation of organic matter.

Chlorophyll $a$ was determined spectrophotometrically after filtration through a whatman $\mathrm{GF} / \mathrm{C}$ filter, extraction in $90 \%$ acetone and centrifugation (Lorenzen 1967). The volume of filtered water varied from 0.5 to $3 \mathrm{~L}$, and samples were duplicated. Values represent an average of the six depths.

\section{Results}

\subsection{Physical and chemical parameters of the lake}

Water temperatures were lowest in January $\left(2^{\circ} \mathrm{C}\right.$ within the whole water column). Then, together with the increase of global radiation and day length, water temperature regulary increased from midFebruary onwards and reached $15^{\circ} \mathrm{C}$ in April (Fig. 2). At that time (end of April to beginning of May), a thermal gradient. (4- $5^{\circ} \mathrm{C}$ as a maximum) regularly appeared ; it disappeared entirely in mid-October when the temperature had decreased to $15^{\circ} \mathrm{C}$. Maximal surface temperatures varied from $22^{\circ} \mathrm{C}$ (1982) to $\left.25^{\circ} \mathrm{C}\right)(1983$ and 1986). Intermittent mixing occurring during that period under wind effect was of major significance for phytoplankton seasonal periodicity (Garnier 1989, 1992). Periods of stratification were generally short and never lasted for more thar. 6 weeks. In 1985 and especially in 1986 when the level of the water was lowered, the amplitude of the thermal gradient was reduced.

A continuous increase in water transparency, $Z_{\mathrm{s}}$ (a decrease in light attenuation coefficient, K) occurred throughout the whole period of the study (Fig. 3). Increases of $Z_{S}$ between 1979 and 1985 were significant according to Kruskal-Wallis test and multiple comparisons. A decrease of $Z_{S}$ was otserved in 1986 when the water level was lowered. Also, during the first four years of the study (1979 to 1982), a seasonal trend in water transparency was observed, with values lower in summer (May to

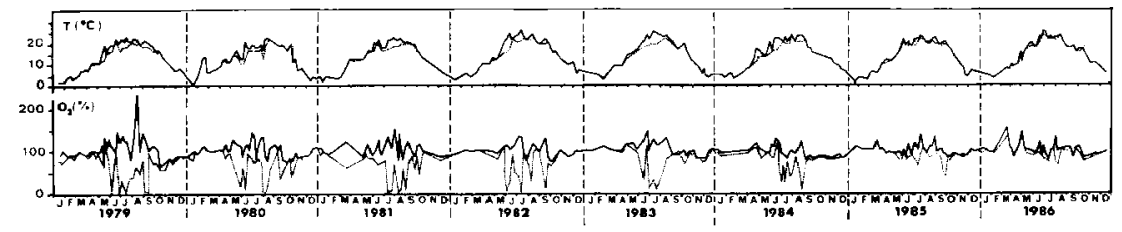

Fig. 2. Interannual variations of temperature $\left(\mathrm{T}:{ }^{\circ} \mathrm{C}\right)$ and percentage saturation of oxygen $\left(\mathrm{O}_{2}: \%\right)$ at the surface $(-)$ and 4 m $(--)$ from 1979 to 1986.

Fig. 2. Variations interannuelles, de 1979 à 1986, de la température $\left(\mathrm{T}:{ }^{\circ} \mathrm{C}\right)$ et du pourcentage de saturation en oxygène $\left(\mathrm{O}_{2}: 0 \%\right.$ en surface (-) et à $4 \mathrm{~m}$ (--). 


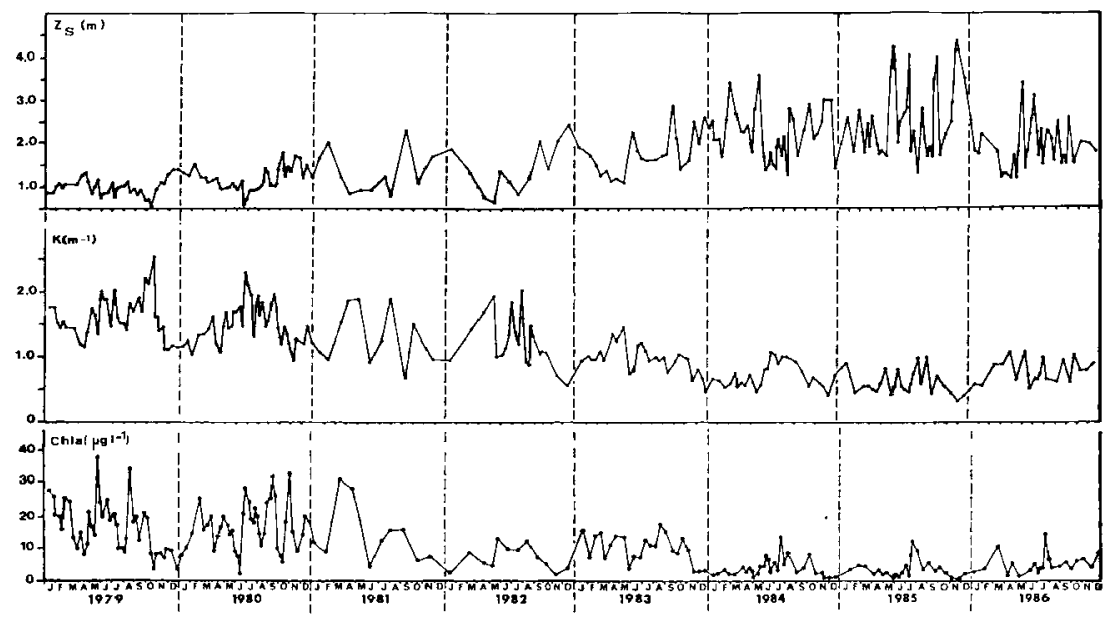

Fig. 3. Interannual variations of water transparency $\left(\mathrm{Z}_{\mathrm{s}}: \mathrm{m}\right)$, of the light attenuation coefficient $\left(\mathrm{K}: \mathrm{m}^{-1}\right)$ and of chlorophyll $a$ concentrations (chl $a: \mu \mathrm{g} \mathrm{I}^{-1}$ ) from 1979 to 1986.

Fig. 3. Variations interannuelles, de 1979 à 1986 , de la transparence de l'eau (Zs : m), du coefficient d'extinction (K : m-1) et de la concentration en chlorophylle $a(\operatorname{chl} a: \mu \mathrm{g} \mathrm{l}-1)$.

October) than in winter (November to April) (Wilcoxon-Mann-Whitney bilateral test). From 1983 onwards, the increase in water transparency was more pronounced, so that no seasonal tendency was observed in 1984 and 1986, mean summer values being even higher than winter values.

At a seasonal scale, three periods can be distinguished with respect to water oxygenation (Fig. 2). From January to April, the whole water column was saturated (values between 90 to $100 \%$ ) ; from May to October, depending on the stratificationdestratification episodes, water was at times supersaturated in the upper column whereas oxygen depletion sometines occurred deeper; at the end of October, oxygen depth profiles were homogeneous but a slight depletion (saturation at $70 \%$ ) was observed, saturation being progressively restored towards December.

From May to October, oxygen depth profiles depended on the thermal structure. Oxygen depletion at the bottom was more pronounced when the thermal gradient has been important for a long period ; oxygen depletion at the bottom was accentuated by the supply of anoxic phreatic waters, circulating through strongly reducing filling material. In addition, when transparency was low at the beginning of the study, as photosynthetic processes were restricted within the upper water layer, differences between surface and bottom were accentuated. Therefore, wind induced intermittent mixing events had an important role in the re-oxygenation of the water column in summer. The undersaturation during autumnal mixing was caused by a considerable demand for dissolved oxygen for the decomposition of organic material produced during the period of maximum biological activity.

Although, as a general rule, oxygen followed the same year to year seasonal pattern, changes have nethertheless been observed throughout the studied period. Differences between surface and bottom have become of lesser importance at the end of the study when the increase in water transparency deepened 
photosynthetic activity (Fig. 2). As an average for the summer period, saturation percentage regularly increased from $48.8 \%$ in 1979 to $88.7 \%$ in 1985 . In 1985 and 1986, minimum values at $4 \mathrm{~m}$ equalled $50 \%$ whereas they decreased to $5 \%$ from 1979 to 1982 (Fig. 2).

\subsection{Changes in chlorophyll a level}

Whereas transparency increase, concentrations in chlorophyll $a$ decrease significantly during the period of the study ; values, in annual means, were the highest (about $15 \mu \mathrm{gl}-1$ ) from 1979 to 1981 , decreased significantly in 1982 and 1983 (7 and $9.5 \mu \mathrm{gl}-1$ respectively) and decreased still further in 1984 and 1985 (4.1 and $3.6 \mu \mathrm{gl}^{-1}$ ) whereas a slight increase occurred in $1986(5.4 \mu \mathrm{gl}-1)$, (Fig. 3). Wide variations in chlorophyll $a$ concentrations were observed at a seasonnal scale. High value in winter were of ten associated to early increases in abundance (not in biomass) of small algal species (Garnier 1989); the highest algal biomass found in summer and determined from cell volume (Garnier 1989) were not accompanied by the the highest values in chlorophyll so that a seasonal trend did not appear clearly.

\subsection{Nutrients in the lake and sources of nutrients}

A nutrient budget is difficult to establish for the Lake Créteil because the hydrodynamic and chemistry of the supplying phreatic water are very complex. The rainwater pipe furthermore complicates the system because, until May 1981, it also brought polluted domestic waters besides rainwaters.

The year-to-year trends in total phosphorus were clearly related to human intervention on the rainwater pipe which decreased the polluted effluents. Total phosphorus concentrations steadily increased in lake water from January 1979 to May 1981, values averaging $32.8 \mu \mathrm{g} \mathrm{l}-1$ in $1979,48.5 \mu \mathrm{g} \mathrm{I}^{-1}$ in 1980 and $71 \mu \mathrm{g} \mathrm{1-1} \mathrm{from} \mathrm{January} \mathrm{to} \mathrm{May} 1981$ (Fig. 4) ; the nutrient diversion caused a decrease to an average of $37.6 \mu \mathrm{g} \mathrm{l}^{-1}$ in the second part of 1981 . From 1982 to 1986, annual average of total phosphorus (between 42 and $50 \mu \mathrm{gl}^{-1}$ ) stabilized in the range of the values found before the increase, although high values were occasionally still observed. The concentrations of orthophosphates decreased at the beginning of the study period and remained at a low level since then (Fig. 4). There was no seasonal trends for both total phosphorus and orthophosphates even when averaging summer (from May to October) and winter data (November to April).
At the beginning of the study, the rainwater pipe constituted a considerable input of phosphorus, but fortunately $80 \%$ of the phosphorus have been shown to precipitate in the sediment (Chestérikoff et al. 1981). The precipitation would explain the relatively low increase in total phosphorus concentration in the lake compared to that in the rainwater pipe : from 1979 to 1980 , concentrations in total phosphorus in the rainwater pipe increased indeed from 1500 to $9000 \mu \mathrm{g} \mathrm{l}^{-1}$, (Table 3, Chestérikoff et al. 1981). In 1985, total phosphorus was analysed in lake water, just below the pipe : high values of phosphorus (P-tot : $119 \mu \mathrm{g} \mathrm{I}^{-1}$ in annual average ranging from 36 to $250 \mu \mathrm{g} \mathrm{1}^{-1}$; P-P04 : $60.6 \mu \mathrm{g} \mathrm{I}^{-1}$ ranging from 4 to $193 \mu \mathrm{g} \mathrm{l}^{-1}$ ) showed that urban waters brought by the rainwater pipe at the end of the study period still constituted a source of nutrients, despite the sewage diversion in May 1981. No apparent increase in phosphorus content has been observed in the lake sediment from 1980 $\left(0.33 \mathrm{mg} \mathrm{cm}^{-3}\right)$ to $1987\left(0.34 \mathrm{mg} \mathrm{cm}^{-3}\right)$.

Phreatic waters also appeared to be a source of phosphorus for the lake ; measurement performed at the beginning of the study from piezometers were indeed higher than those of the lake (Table 3, Chestérikoff et al. 1981).

Total inorganic nitrogen ( $\mathrm{N}$-tot) decreased at the beginning of the study, from 1.08 to $0.75 \mathrm{mg} \mathrm{l-1}$ between 1979 and 1980 as an annual average (from 3.9 to $1.15 \mathrm{mg} \mathrm{l}^{-1}$ for maximal values) but also drastically decreased in May 1981 ; values stabilized around $0.3 \mathrm{mg} \mathrm{l}^{-1}$ from 1982 to 1986 (Fig. 5). The decrease in total inorganic nitrogen resulted from a simultaneous decrease of both ammonium and nitrate representing respectively $2 / 3$ and $1 / 3$ of total inorganic nitrogen.

Despite some irregularity in the seasonal pattern, nitrate tended to decrease in summer, this tendency being apparent at the beginning of the study when higher values were found (Fig. 5). No seasonal trend was found for ammonium, excepted in 1979.

Similarly to phosphorus, the pipe and phreatic waters constituted a source of nitrogen ; concentration in total inorganic nitrogen (N-tot) in the pipe waters (18.7 $\left.\mathrm{mg} \mathrm{l}^{-1}\right)$ as well as in the phreatic waters (from zero to $150 \mathrm{mg} \mathrm{l}^{-1}$ depending on the situation of piezometers, median value of $12 \mathrm{mg} \mathrm{1}^{-1}$ (Table 3) were much higher than in the lake water $\left(1 \mathrm{mg} \mathrm{l}^{-1}\right)$. In 1985, nitrate concentrations (N-NO $)$ 


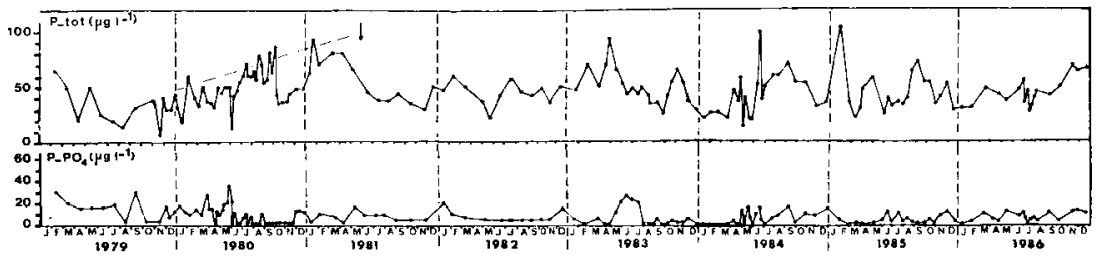

Fig. 4. Interannual variations of total phosphorus (P-tot) and orthophosphates $\left(\mathrm{P}_{-} \mathrm{PO}_{4}\right)$ from 1979 to 1986 . Concentrations in $\mu \mathrm{gP} \mathrm{i}^{-1}$. Fig. 4. Variations interannuelles, de 1979 à 1986 , du phosphore total (P-tot) et des orthophosphates (P-PO $)$. Concentrations en $\mu$ gP $]^{-1}$.

Table 3. Concentrations in nutrients of phreatic and pipe waters between 1978 and 1980 (Chestérikoff et al. 1981). Phreatics waters : mean (x) and extreme values (ext) for 8 piezometers, ${ }^{*} 12$ $\mathrm{mg} \mathrm{l}^{-1} \mathrm{~N}$-tot is the median value for 8 piezometers. Pipe waters :

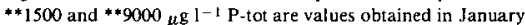
1979 and December 1980, values increasing in an exponential way during that time interval (cf. p. 27, fig. 16: Chestérikoff et al 1981 ) mean (x) and extreme values (ext) for $\mathrm{N}$-tot and $\mathrm{N}-\mathrm{NH}_{4}$,

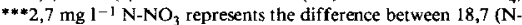
tot) and $16\left(\mathrm{~N}-\mathrm{NO}_{3}\right)$ (Chestérikoff et al. 1981). Concentration in nutrients of lake water below the pipe outfall : Mean $(x)$ and extreme values (ext) for 13 sampling dates.

Tableau 3. Concentrations en éléments nutritifs dans la nappe et dans le collecteur entre 1978 et 1980 (Chestérikoff et. al. 1981) et à la sortie du collecteur en 1985. Dans la nappe : valeurs moyennes (x) et extrêmes (ext) pour 8 piezomètres, ${ }^{*} 12 \mathrm{mg} \mathrm{l}^{-1} \mathrm{~N}$-tot est la valeur médiane pour 8 piezomètres. Eaux du collecteur : ** 1500 and $* * 9000 \mu \mathrm{g} \mathrm{I}^{-1}$ sont des valeurs obtenues en janvier 1979 et en décembre 1980 , les valeurs augmentant exponentiellement pendant cet intervalle de temps (cf. p. 27, Fig. 16 : Chesté. rikoff et al. 1981) ; moyenne (x) et valeurs extrêmes (ext) pour $\mathrm{N}$-tot et $\mathrm{N}-\mathrm{NH}_{4},{ }^{* * * 2,7} \mathrm{mg} \mathrm{l}^{-1}, \mathrm{~N}-\mathrm{NO}_{3}$ représentant la différence entre 18,7 ( $\mathrm{N}$-tot) et $16\left(\mathrm{~N}-\mathrm{NO}_{3}\right)$ (Chestérikoff et al. 1981). Concentrations en éléments nutritifs dans le lac à la sortie du collecteur : moyenne $(x)$ et valeurs extrêmes (ext) pour 13 dates échantillonnées.

\begin{tabular}{|c|c|c|c|c|}
\hline \multirow{2}{*}{\multicolumn{3}{|c|}{ phreatic watere }} & \multicolumn{2}{|c|}{ rainwater pipe } \\
\hline & & & within & outfal1 \\
\hline & & $1978-1980$ & $1978-1960$ & 1985 \\
\hline$\left(\begin{array}{l}p-t o t \\
\left(\operatorname{kg} 11^{-3}\right)\end{array}\right.$ & $\begin{array}{c}x \\
\text { ext }\end{array}$ & $\begin{array}{c}85 \\
5-240\end{array}$ & 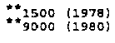 & $\begin{array}{c}219 \\
35-250\end{array}$ \\
\hline$\underset{(\mu \mathrm{g}}{\mathrm{P}-\mathrm{PO}_{4}}$ & $\underset{e x t}{x}$ & $\begin{array}{c}25 \\
5-105\end{array}$ & & $\begin{array}{l}60.5 \\
4-193\end{array}$ \\
\hline$\left(\begin{array}{ll}N-\operatorname{tot} \\
(\mathrm{mg} 1\end{array}\right.$ & $\begin{array}{l}x \\
\text { ext }\end{array}$ & ${ }^{*} 12$ & $\begin{array}{r}18.7 \\
7-28\end{array}$ & \\
\hline $\mathrm{N}-\mathrm{NH}_{4}$ & $\underset{\text { ext }}{x}$ & & $\begin{array}{l}16 \\
5-28\end{array}$ & \\
\hline $\mathrm{N}-\mathrm{NG}_{3}$ & $\underset{\text { ext }}{x}$ & & $* * 2.7$ & $\begin{array}{c}0.37 \\
0.09-0.56\end{array}$ \\
\hline
\end{tabular}

just below the pipe $\left(0.37 \mathrm{mg} 1^{-1}\right.$, from 0.09 to 0.56 $\mathrm{mg} \mathrm{l}^{-1}$ in extreme values) higher than those in the lake show that the rainwater pipe was still a source of nitrogen.

There was no coincidence between maximum values of total phosphorus and inorganic nitrogen in the lake.

\section{Discussion}

\subsection{Typical seasonal features of the physical and chemical environment}

As shown by the vertical distribution of oxygen concentrations, a slight thermal gradient is sufficient to offer a resistance to exchanges between surface and bottom but, mixing events invariably reduced the duration of bottom deoxygenation. The increase in water transparency, favouring a relative increase in photosynthetic activity deeper, has attenuated the strong heterogeneity of oxygen profiles observed at the beginning of the study.

The decrease in transparency during summer for 1979 to 1982 coincided to the maximum of phytoplankton biomass. However, after 1982, the summer phytoplankton biomass was too low to influence the seasonal trend in transparency. Seasonal fluctuations of chlorophyll $a$ concentrations were clearly associated to the main phases of phytoplankton growth and decline, although high chlorophyll values, compared to phytoplankton biomass, were found in winter (Garnier 1989, Lacroix et al. 1989). These wide variations appear to be typical of shallow waters, where mixing events create new conditions (nutrient release) which enhance phytoplankton growth. 


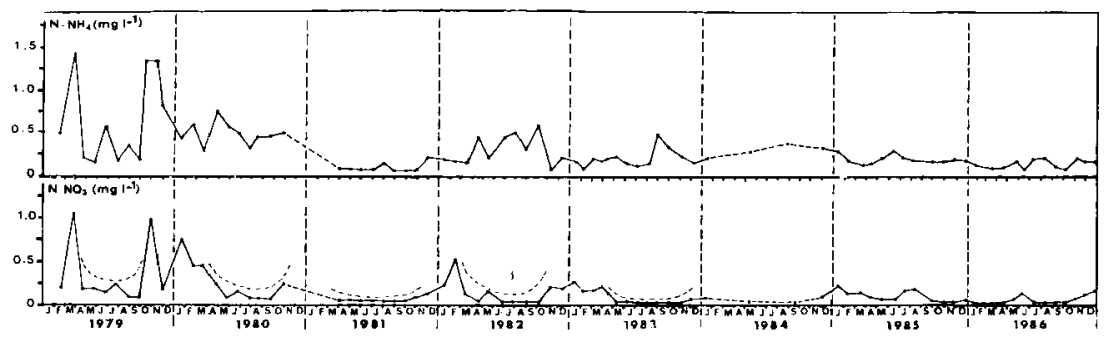

Fig. 5. Interannual variations of ammonium $\left(\mathrm{N}-\mathrm{NH}_{4}\right)$ and nitrate $\left(\mathrm{N}-\mathrm{NO}_{3}\right)$ from 1979 to 1986 . Concentrations in mgN $1-1$.

Fig. 5. Variations interannuelles, de 1979 à 1986, en ammoniaque $\left(\mathrm{N}-\mathrm{NH}_{4}\right)$ et nitrates $\left(\mathrm{N}-\mathrm{NO}_{3}\right)$. Concentrations en mgN $1^{-1}$.

The summer decrease in nitrates at the beginning of the study must be related to phytoplankton uptake but also, as anaerobic conditions developped, to denitrification processes important in sandpit lake (Labroue et al. 1988). The other forms of nutrients have not shown any clear seasonal pattern. This could indicate a rapid biological uptake together with rapid exchanges between water and sediment during mixing events.

\subsection{Characteristics of the physical and chemical changes over the 8 years studied}

From 1979 onwards, the increase in water transparency has been the most significant and directly observable characteristic of the development. Suspended matter (dry weight) have not been continously analysed but between 1978 (Chestérik off et al. 1981) and 1985 (Mourelatos 1988), a decrease from 13 to $6 \mathrm{mg}^{-1}$ as an annual average has occurred. The reduction in suspended matter partly corresponded to a decrease of the organic fraction (a decrease in chlorophyll $a$ concentration from 17 to $3.5 \mu \mathrm{g} \mathrm{I}^{-1}$ in annual means) throughout the period studied. However, as the decrease in water transparency has been observed as early as 1980 whereas chlorophyll $a$ concentrations began to decrease only in 1982, the biological component alone cannot explain the increase in transparency. It must also be related to a progressive stabilization of bottom sediment and banks, after the quarrying of sand has stopped, thus reducing resuspension by wind and littoral turbulence. In 1986, when the lake water level was lowered, the reversed trend can conversely be explained by erosion of the banks as well as by increased resuspension of the bottom sediments. An indirect but important effect of the increase in water transparency was to improve the oxygenation of the water column.

Whereas direct superficial inputs in nutrients are obviously an important source for eutrophication, the rapid decrease in chlorophyll after nutrient reduction has shown the lake to be very sensitive to restoration.

The diversion of domestic water brought by the rainwater pipe until May 1981 is the main cause for the decrease in phosphorus in the lake. The early decrease in nitrogen, but also in orthophosphates, tends to support the idea of a reduction of nutrients brought by the phreatic waters, after progressive wash out of nutrients from polluted material. Later on in 1983, the regulation of the water level of the lake by a drainage pipe, decreasing the residence time, coincided with an accentuation of oligotrophication, but no effect of residence time can be shown for the nutrient conditions found in the lake in 1983 (Garnier \& Billen, in press). Other processes including colonisation of macrophytes could have contributed to a progress in the oligotrophication of the lake.

Internal processes must have also contributed to the elimination of nutrients.

The hard waters of Lake Créteil represented favourable conditions for a transfer of large fraction of the phosphorus input to calcium, explaining the precipitation as calcium phosphates and thus 
limiting the increase in phosphorus concentration in the lake (Tiren \& Petersson 1985 ; Herodek \& Istvanovics 1986). Whereas a large part of phosphorus was therefore immobilized in the sediments (Bates \& Neafus 1980, Bostrom et al. 1982, Foy 1986), an other part must be however permanently recycled either under intermittent stratificationdestratifications, by mineralization of organic phosphorus under oxic conditions (Kamp-Nielsen 1975, Lee et al. 1977) or by biological uptake and adsorption-desorption processes on suspended matter within the lake water (Capblancq et al. 1986).

Considering nitrogen, denitrification could be a major process for its elimination. In Lake Créteil chiefly at the beginning of the study, the supply with anoxic water and intermittent oxygen depletion together with a high algal biomass in summer represented suitable conditions for denitrification (Barroin 1985, Labroue et al. 1988). Denitrification might partly explain the difference between nitrate concentrations in the lake (1 $\left.\mathrm{mg} \mathrm{l}^{-1}\right)$ and in phreatic waters and in waters brought by the pipe (12 and $18 \mathrm{mg}$ $1^{-1}$ respectively) ; it is improbable that the difference could have been mobilized by phytoplankton. In 1985, particulate nitrogen for the fraction less than $35 \mu \mathrm{m}$ were $0.1 \mathrm{mg} \mathrm{l}^{-1}$; taking into account the reduction in phytoplankton biomass (from 17 to $3.5 \mu \mathrm{g} \mathrm{l}^{-1}$ in chlorophyll a) particulate nitrogen should be less than $1 \mathrm{mg} \mathrm{l}^{-1}$ at the beginning of the study.

\section{References}

Barroin G. 1985. - La dénitrification en milieu lentique. Rev. franc. Sci. Eau 4 : 79-92.

Bates N.H. \& Neafus N. Jo E. 1980. - Phosphorus release from Lake Carl Blackwell, Oklaoma. Water Research 14: 1477-148I

Boström B., Janson M. \& Forberg C. 1982. - Phosphorus release from lake sediments. Arch. Hydrobiol. Ergebn. Limnol. $18: 5-59$.

Brock T.D. 1985. - Chemistry and nutrient loading, $p: 43-83$. In : A Eutrophic lake, Lake Mendota. Billing, W.D., Golley, F., Lange, O.L., Olson, J.S. \& Remmert, H. (eds). Springer Verlag, New York, 308 p.

Billing W.D., Golley F., Lange O.L., Olson J.S. \& Remmert H. (eds) 1985. - A eutrophic lake, Lake Mendota. Springer Verlag, New York, $308 \mathrm{p}$.

Chestérikoff A. 1981. - Etude de la qualité des eaux du lac de Créteil (Val-de-Marne). Rapp. Inst. Hydrol. Climat (après deux ans d'étude). Univ. Paris VI $57 \mathrm{p}$.

Chestérikoff A., Chevreuil M., Lecolle P., Gerdeaux D. \& Testard P. 1981. - Ecologie du lac de Créteil (Val de Marne). Edit. département Val-de-Marne 77 p.
Chestérikoff A. \& Chevreuil M. 1987. - Hydrogéologie de la plaine alluviale de Créteil, Val-de-Marne. Rev. franc. Scr. Eau $6: 449-472$.

Capblancq J., Labroue L. \& Fardeau J.C. 1986. - Echanges de phosphore entre les sédiments et l'eau. Influence de la dilution sur les cinétiques de traçage isotopiques. Ann/s. Limnol. $22: 277-283$.

Caspers S.J. (ed). 1985. - Lake Stechlin. A temperate oligotrophic lake. $\mathrm{D}^{\mathrm{r}}$. W. Junk Publishers, Boston, $553 \mathrm{p}$.

Foy R.H. 1986. - Suppression of phosphorus release from lake sediments by the addition of nitrate. Wat. Res. $20: 1345-1351$.

Garnier J. 1989. - Peuplement phytoplanctonique et bactéries hétérotrophes d'un lac peu profond (Lac de Créteil, région parisienne). Production, fonctionnement, évolution. Thèse de Doctorat es Science, Univ. Paris $6: 331 \mathrm{p}$.

Garnier J., Lelong J.-F. \& Meybeck M. 1987. - Comparaison physico-chimique et biologique de sept bassins artificiels dans les alluvions de la région parisienne. Noturaliste can. (Rev. Ecol, Syst.) $114: 325-342$.

Garnier J. 1992. - Typical and atypical features of phytoplankton in a changing environment : eight years of oligotrophication in a recently created sand-pit lake, Créteil Lake, Paris suburb, France). Arch. Hydrobiol. 125: 463-478.

Garnier J. \& Billen G. in press. - Ecological interactions in a shallow sand-pit lake (Créteil Lake, Parisian Basin, France) : a modelling approach. In : Shallow and brackisch lakes, Development in Hydrobiologia.

Herodek S. \& Istvanovics V. 1986. - Mobility of phosphorus fractions in the sediments of Lake Balaton. Hydrobiologia $135: 149-154$.

Kamp-Nielsen L. 1975. - Seasonal variations in sediment-water exchange of nutrient ions in Lake Esrom. Verh. Internat. Ver. Limnol. 19 : 1057-1065.

Labroue J., Tourenq J.-N., Mieussens C., Robert J. \& Donville B. 1988. - Rôle des gravières dans la diminution des teneurs en nitrates des aquifères alluviaux de la vallée de la Garonne. Essai de quantification. Annls. Limnol. 24 : 31-38.

Lacroix G., Boët Ph., Garnier J., Lescher-Moutoué F., Pourriot R. \& Testard P. 1989. - Factors controlling the planktonic community in the shallow Lake of Créteil, France. Int. Revue ges. Hydrobiol. $74: 353-370$.

Lee F.G., Sonzogni W.C. \& Spear R.D. 1977. - Significance of oxic vs anoxic conditions for Lake Mendota sediment $s$ and freshwater : 294-306. In : Proc. Int - Symp. Amsterdam. $D^{r}$. Junk Publishers, the Hague.

Likens G.E. (ed). 1985. - An ecosystem approach to aquatic ecology. Mirror lake and its environment. Springer Verlag. New York, $516 \mathrm{p}$.

Mourelatos S. 1988. - Broutage du phytoplancton par le zooplancton dans un lac peu profond. Thèse de Doctorat 3 eycle, Univ. Paris VI, 193 p.

Tiren T. \& Pettersson K. 1985. - The influence of nitrate on the phosphorus flux to and from oxygen depleted lake sediments. Hydrobiologia $120: 207-223$.

Thornton K.W., Kimmel B.L. \& Payne F.E. (eds). 1990. Reservoir limnology, ecological perspectives. John Wiley \& Sons, Inc, New York, $246 \mathrm{p}$. 